\title{
Long-Term Persistence of Spike Antibody and Predictive Modeling of Antibody Dynamics Following Infection with SARS-CoV-2
}

Louis Grandjean MBBS ${ }^{1,2^{*}}$, Anja Saso MBBS ${ }^{2,3,4^{*}}$, Arturo Torres Ortiz MSc ${ }^{1,5^{* \star}}$, Tanya Lam MBBS $^{2^{* *}}$, James Hatcher MBBS ${ }^{6}$, Rosie Thistlethwayte BA ${ }^{7}$, Mark Harris ${ }^{8}$, Timothy Best $\mathrm{BSc}^{5}$, Marina Johnson $\mathrm{PhD}^{1}$, Helen Wagstaffe $\mathrm{PhD}^{1}$, Elizabeth Ralph $\mathrm{MSc}^{9}$, Annabelle Mai $\mathrm{MSc}^{9}$, Caroline Colijn $\mathrm{PhD}^{10}$, Judith Breuer MBBS ${ }^{1}$, Matthew Buckland $\mathrm{PhD}^{9}$, Kimberly Gilmour $\mathrm{PhD}^{9}$, David Goldblatt MB ChB ${ }^{1}$ for the Co-Stars Study Team ${ }^{2 \dagger}$

${ }^{*}$ Contributed equally ( $L G$ is also corresponding author)

${ }^{*}$ Contributed equally

+Co-Stars Study Team members listed in the acknowledgement section

\section{Author}

1Department of Infection, Inflammation and Immunity, Great Ormond Street Institute of Child Health, University College London, 30 Guilford Street, London, UK WC1N 1EH

${ }^{2}$ Department of Infectious Diseases, Great Ormond Street Hospital, Great Ormond Street, London, WC1N 3JH

${ }^{3}$ Department of Tropical and Infectious diseases; LSHTM, Keppel St, Bloomsbury, London WC1E 7HT

${ }^{4} \mathrm{MRC}$ Gambia at LSHTM, PO Box 273, Fajara, The Gambia

${ }^{5}$ Department of Medicine, Imperial College, Paddington, London, W2 1NY

${ }^{6}$ Department of Microbiology, Great Ormond Street Hospital, Great Ormond Street, London, WC1N 3JH

${ }^{7}$ Management, Great Ormond Street Hospital, Great Ormond Street, London, WC1N 3JH

${ }^{8}$ Quality Improvement, Great Ormond Street Hospital, Great Ormond Street, London, WC1N 3JH

${ }^{9}$ Clinical Immunology, Camelia Botnar Laboratories, Great Ormond Street Hospital, Great Ormond Street, London, WC1N 3JH

${ }^{10}$ Department of Mathematics, Simon Fraser University, Vancouver, British Colombia, Canada BC V5A 


\section{Corresponding author contact details}

Dr Louis Grandjean

Department of Infection, Inflammation and Immunity, Institute of Child Health, 30 Guilford Street, London, WC1N l.grandjean@ucl.ac.uk

Summary: This study demonstrates persistence of the spike antibody and decay of the nucleoprotein antibody in serial samples from 349 patients up to 200 days post SARS-CoV-2 infection. We also provide a mathematical modelling framework to predict long term immune responses following SARS-CoV-2. 


\section{Abstract}

Background: Antibodies to Severe Acute Respiratory Syndrome Coronavirus-2 (SARSCoV-2) have been shown to neutralize the virus in-vitro and prevent disease in animal challenge models upon re-exposure. However, current understanding of SARS-CoV-2 humoral dynamics and longevity is conflicting.

Methods: The Co-Stars study prospectively enrolled 3679 healthcare workers to comprehensively characterize the kinetics of SARS-CoV-2 spike (S), receptor-bindingdomain (RBD) and nucleoprotein (N) antibodies in parallel. Participants screening seropositive had serial monthly serological testing for a maximum of 7 months with the Mesoscale Discovery Assay. Survival analysis determined the proportion of sero-reversion while two hierarchical Gamma models predicted the upper- and lower-bounds of long-term antibody trajectory.

Results: A total of 1163 monthly samples were provided from 349 seropositive participants. At 200 days post-symptoms, $>95 \%$ of participants had detectable S-antibodies compared to $75 \%$ with detectable $\mathrm{N}$-antibodies. S-antibody was predicted to remain detectable in $95 \%$ of participants until 465 days $[95 \% \mathrm{Cl} 370-575]$ using a 'continuous-decay' model and indefinitely using a 'decay-to-plateau' model to account for antibody secretion by long-lived plasma cells. S-antibody titers correlated strongly with surrogate neutralization in-vitro $\left(R^{2}=0.72\right)$. $N$-antibodies, however, decayed rapidly with a half-life of 60 days [95\% $\mathrm{Cl} 52-68$ ].

Conclusions: The Co-STAR's study data presented here provides evidence for long-term persistence of neutralizing S-antibodies. This has important implications for the duration of functional immunity following SARS-CoV-2 infection. In contrast, the rapid decay of $\mathrm{N}$ antibodies must be considered in future seroprevalence studies and public health decisionmaking. This is the first study to establish a mathematical framework capable of predicting long-term humoral dynamics following SARS-CoV-2 infection.

\section{Key words}

Immunity, serology, antibody, ELISA, kinetics, neutralization, SARS-CoV-2, COVID-19, virus, nucleoprotein, spike protein

Trial registration number: NCT04380896. 


\section{Introduction}

Since appearing as a cluster of pneumonia cases in Wuhan, China, Coronavirus disease (COVID-19) caused by Severe Acute Respiratory Syndrome Coronavirus-2 (SARS-CoV-2) has rapidly spread worldwide [1]. As of 24th April 2021, there have been 145,774,566 recorded cases globally, resulting in over 3 million deaths [2]. Specific immunoglobulin ( $\mathrm{lgG}$ ) antibody responses to the SARS-CoV-2 trimeric spike (S) protein, nucleoprotein $(\mathrm{N})$ protein and the receptor-binding domain (RBD) develop between 6-15 days following disease-onset [3]. The S-protein, which contains the RBD, binds to host cells via the angiotensin-converting-enzyme-2 (ACE-2) receptor, and membrane fusion occurs before viral entry $[4,5]$. The $\mathrm{N}$-protein plays an important role in transcription enhancement and viral assembly [6].

Neutralizing SARS-CoV-2-specific antibodies to the S- and RBD-antigens, have been shown to correlate with viral neutralization in vitro as well as to protect against disease in animals following passive transfer of convalescent or monoclonal antibodies [7-11]. It is unclear, however, whether re-infection can occur in humans who mount a humoral response following primary SARS-CoV-2 infection and achieve viral clearance. Neutralizing SARSCoV antibodies have been shown to commonly persist up to 2-3 years post-infection, particularly in hospitalized patients, $[12,13]$ with recent reports demonstrating seropositivity as late as 12-17 years after infection [14,15]. Existing longitudinal studies of SARS-CoV-2 are limited by inadequate modeling of antibody dynamics, short duration, low sampling density and insufficient frequency of follow-up [16-26]. Fitting Locally Estimated Scatterplot Smoothing (LOESS) or equivalent lines of best fit to the data also fails to provide a mathematical framework for evaluating long-term antibody responses [16-18,27].

In order to evaluate antibody kinetics and longevity following SARS-CoV-2 infection, we undertook the prospective Covid-19 Staff Testing of Antibody Responses Study (CoSTARS). Detailed demographic, clinical and socioeconomic data were collected and mathematical models developed to characterize longitudinal humoral kinetics from initial antibody boosting to subsequent decay. To predict long-term antibody dynamics, we fitted two different models based on the gamma distribution: one which assumed persistent antibody decay [28], and an alternate that allowed for an eventual plateau, to account for sustained antibody production by long-lived plasma cells (LLPCs) $[29,30]$. 


\section{Results}

\section{Participant Demographics}

A total of 3679 healthcare workers at Great Ormond Street Hospital were enrolled in the study of which $733 / 3679$ (19.9\%) were SARS-CoV-2 seropositive by the EDI ${ }^{\mathrm{TM}}$ ELISA. Of these seropositive participants $49 \%$ were completely asymptomatic (359/733). Of those that were symptomatic, 349 were confirmed seropositive by the MSD assay and provided 2 or more monthly samples for the primary outcome analysis of antibody dynamics (Table 1). This group were followed up monthly for a maximum of 7 months and provided 1163 serial monthly serological samples. The median follow-up time per participant was 122 days (IQR 65 - 157 days) with a maximum follow up time of 262 days from symptom onset. The majority of participants 252/349 (72\%) donated 3 or more samples with a maximum of 7 samples donated during follow up. Most seropositive participants were women (80\%) with a mean age of 39 years representative of the underlying population structure of the hospital. The predominant symptoms reported were cough $225 / 349$ (64\%), myalgia $225 / 349$ (64\%), followed by ageusia and anosmia at 210/349 (60\%) and 201/349 (58\%) respectively.

\section{Factors Associated with Increased Peak Antibodies and Rapid Decay}

Multivariate analysis demonstrated that fever, rigors, ageusia, anosmia, high BMI and Black Asian Minority Ethnic (BAME) backgrounds were all associated with higher peak spike protein antibody titers (Table 1). No variables were identified to be independently associated with the rate of antibody decay.

\section{Observed Antibody Kinetics and Seroreversion}

Serial monthly serological measurements from 349 participants demonstrated a rapid rate of decay of the $\mathrm{N}$-antibody relative to the $\mathrm{S}$ and RBD antibody (Figure 1 ). The $\mathrm{S}$-antibody assay detected a total of $342 / 349$ (98\%) participants who were seropositive to any one of the S, RBD or N-antibodies. In comparison the RBD and $\mathrm{N}$-assays detected $332 / 349(95 \%)$ and $333 / 349(95 \%)$ respectively. The sensitivity of the RBD and $\mathrm{N}$-assays further declined with time relative to the $\mathrm{S}$-antibody assay. At 150 days post infection 249 out of the 349 participants initially seropositive for the $\mathrm{N}$-antibody provided samples for analysis. Only 233 of 249 remained positive to the $\mathrm{N}$-antibody (survival probability $95 \% \mathrm{Cl}$ 0.86-0.93) while significantly more, 247 of 249 (survival probability $95 \% \mathrm{Cl} 0.95-0.99$ ) remained positive to the S-antibody. At 200 days post infection 19 samples were available for comparison, of which 15 remained positive to the $\mathrm{N}$-antibody (survival probability $95 \% \mathrm{Cl} 0.56-0.80$ ) while 19 remained positive to the S-antibody (survival probability $95 \% \mathrm{Cl} 0.95-0.99$, Figure 2 ). 


\section{Modeled Serological Reversion and Proportion of Positive Tests Over Time}

Comparison of goodness of fit between models showed that for all antigens the decay-toplateau model provided a better fit to the data than the gamma-decay model, although this difference was not statistically significant (Supplementary data, table S2). Even under the most pessimistic assumption of continuous gamma-decay we estimate that $95 \%$ of individuals following infection with SARS-CoV-2 will have measurable S-antibody until 465 days [95\% Cl 370-575] after the symptom start date. Under the gamma-plateau model Santibody is predicted to remain detectable indefinitely (Figure 3a) [15]. The most pessimistic gamma-decay model (lower bound) and most optimistic gamma-plateau model (upper bound) for each antibody are shown in Figure $3 \mathrm{~b}$. Under both models the $\mathrm{N}$-antibody decayed to undetectable levels. Even under the gamma-plateau model, $75 \%$ of participants were predicted to have seroreverted $\mathrm{N}$-antibody by 610 days [95\% $\mathrm{Cl} 420-530$ ] whereas under the gamma-decay model $100 \%$ of participants had seroreverted $\mathrm{N}$-antibody by 460 days [95\% Cl 420-530] following symptom onset. Fewer serial samples beyond 200 days post symptom-onset increased the uncertainty in our longer-term modeled estimates of antibody duration (shaded areas Figure 3).

\section{Antibody Peak, Half-Life and Plateau}

Antibody titers rapidly increased during the first 3 weeks with prolonged high titers reached and maintained between week 4 and week 10 after symptom onset. The peak antibody response for the S-antibody, $\mathrm{RBD}$, and $\mathrm{N}$-antibody from both raw weekly average serial titer and modeled data occurred at 40 days [95\% $\mathrm{Cl} 30-63$ ], 31 days [95\% $\mathrm{Cl} 26-38$ ], and 35 days [95\% Cl 31-42] respectively. This was supported by the both the gamma-decay and gammaplateau models which provided a similar close fit to this early stage of the humoral response (Figure 4a, b, c).

The modeled half-life under the gamma-decay model and the gamma-plateau model were also very similar and both models showed a rapid decay of the $\mathrm{N}$ - relative to the RBD- and S-antibody. The half-life for the N-, RBD- and S-antibody was 60 days [95\% Cl 52-68], 102 days [95\% Cl 92-114] and 126 days [95\% Cl 112-146] respectively under the gamma decay model, while the half-lives under the gamma-plateau model were 60 days [95\% $\mathrm{Cl} 52-70$ ], 110 days [95\% $\mathrm{Cl} 74-148]$, and 364 days [95\% $\mathrm{Cl} 212-997]$ respectively (Figure 4d and e).

Under the gamma-plateau model, the S-antibody was predicted to decay slowly, reaching an eventual stabilized plateau at 1825 days since symptom-onset [95\% Cl 250-3700], at which point the titer still remained above the threshold for a negative test; the $\mathrm{N}$-antibody, on the 
other hand, was predicted to decay to a plateau by 610 days, crossing the threshold for a negative test.

\section{Surrogate Neutralization Assay}

There was a sigmoidal relationship between raw antibody titers and percentage binding/ACE-2 receptor blocking for both the S- and RBD-antibodies. Above a threshold Santibody titer of 8586 [95\% Cl 8160-9095] there was a dramatic increase in percentage binding/ACE-2 receptor blocking. Log-transformed antibody titers were strongly positively correlated with receptor blocking $\left(\mathrm{R}^{2}=0.72 \mathrm{~S}\right.$ - and $\mathrm{R}^{2}=0.77 \mathrm{RBD}$-antibodies). We mapped the point of greatest change in neutralization and the lower limit of detection to the final predicted antibody titers at the plateau (Figure 5). Whilst the full range of the distribution of S-antibodies were predicted to remain detectable indefinitely under the gamma-plateau model, only a small proportion of individuals were predicted to have titers sufficient to enable measurable functional binding under our surrogate neutralization assay.

\section{Discussion}

This prospective cohort study of antibody responses following symptomatic SARS-CoV-2 infection has demonstrated that $>95 \%$ of healthcare workers had persistent detectable spike protein antibodies up to 200 days post infection. Our study is the first to provide a mathematical modeling framework capable of predicting the long-term dynamics of the 3 key SARS-CoV-2 antibodies following natural infection. Even under our most pessimistic assumptions of continuous exponential decay, $95 \%$ of individuals were predicted to remain seropositive to S-antibody at 465 days $[95 \% \mathrm{Cl} 370-575$ days] while our more optimistic upper bound gamma-decay model predicted a permanent long-lasting plateau of detectable S-antibody.

These data contradict conclusions from studies that have reported rapid waning of antibodies after a few months [22,24,25]. Our findings are consistent with the duration of humoral responses observed following SARS-CoV and MERS infections, however, modelling of the S-antibody trajectory under the MSD assay suggests that in the longer-term there is a potential to lose neutralizing capability despite having detectable IgG [12-15]. Importantly, the long-lasting S- and RBD-antibodies also correlated well with a surrogate SARS-CoV-2 neutralization assay of ACE-2-receptor-blocking, strongly suggesting that longterm measurable S-antibody levels are functionally important. 
In contrast to the S-antibody, the N-antibody was observed to serorevert in $56 / 349$ participants over the course of the study alone and had a modeled half-life of 60 days. This has important implications for diagnostic testing, epidemiological modeling and public health decision making that often rely on the $\mathrm{N}$-antibody to estimate SARS-CoV-2 seroprevalence. This finding may also explain some unexpectedly low estimates of population prevalence in high burden countries [31].

The persistence of detectable S- and/or RBD-antibody compared to the rapid decay of the $\mathrm{N}$-antibody has also been observed in convalescent sera obtained from SARS survivors, seventeen years after infection [14]. The mechanisms underlying this observation warrant further investigation. Differences in the epitope structure [32], immunogenicity and presentation to B-cells may impact the production, maturation and longevity of the plasma cells that secrete these antibodies [33-36]. Distinct T-helper cell interactions at the germinal centre may further determine B-cell and humoral dynamics, as previously observed in the context of the response to different HIV proteins [37]. The N-protein is more conserved across CoVs than RBD, potentially leading to cross-reactive memory responses, with differing kinetics and less contribution from naïve B-cells [38].

To date, no studies have comprehensively modeled the nature and duration of antibody responses to different SARS-CoV-2 epitopes. Long [19], Seow [22] and Ibarrondo et al [20], demonstrated rapid decay of SARS-CoV-2 antibodies within the first 3 months following infection, particularly in mildly symptomatic cases. In comparison, others have reported that the S-antibody and/or RBD-antibody correlate with neutralizing responses and decay slowly, persisting during the study period, up to at 90-150 days post-infection [16-18,39]. These studies, however, are limited by their shorter sampling time frame, lower sampling density and lack of appropriate modeling to predict antibody trajectory. Implementing LOESS lines of best fit to the data [16-18,22] or comparing the variance of average antibody titers at different time intervals $[24,25,39]$ does not permit evaluation of long-term antibody trajectory.

Our study is strengthened by the density, frequency and duration of sampling collection. The parallel evaluation of antibody titers by the chemiluminescent MSD assay to three major SARS-CoV-2 proteins also enabled us to demonstrate the decay of the $\mathrm{N}$-antibody relative to the S- and RBD-antibodies. Importantly, this is the first study to provide a mathematical framework for long-term SARS-CoV-2 antibody responses, modeling both the peak and decay following infection and enabling realistic best-case and worst-case predictions as well as considering the impact of LLPCs on future antibody titers. Our work provides a detailed, shareable and reproducible model, with parameters that are useful for epidemiological purposes.

None of the seropositive healthcare workers identified in this study required hospitalization. Given that the majority of COVID-19 cases are managed in the community, our study cohort 
is therefore representative of most SARS-CoV-2 infections in the general population [40]. Severe disease, however, has been associated with higher SARS-CoV-2 antibody titers and potentially a longer lasting humoral response. Recent studies have also hypothesized that previous exposure to seasonal CoVs - to which paediatric healthcare workers may be disproportionately exposed - may confer some protection against SARS-CoV-2 [11,14,4146] and may therefore need to be accounted for when modeling transmission or longevity dynamics [47]. However, recently published work from our group has demonstrated that those with previous exposure to seasonal coronavirus demonstrated little SARS-CoV-2 pseudo-neutralizing activity thereby limiting its impact on our findings [48].

Furthermore, only $38 \%$ of participants in the study had an available confirmatory positive PCR result. To mitigate this concern, a formal evaluation of the MSD assay was undertaken prior to study commencement, using 169 SARS-CoV-2 PCR-positive participants; $97.9 \%$ sensitivity and $97.4 \%$ specificity was demonstrated at 21 days post-infection [48]. This makes the proportion of false positive serological tests likely to be small and therefore have little impact on our findings. The use of a screening ELISA prior to the chemiluminescent MSD assay may also have resulted in some participants being incorrectly classified as seronegative, particularly those with low level detectable $\mathrm{N}$-antibodies. A more sensitive screening test, however, would likely lead to an earlier time-to-negative N-protein trajectory, thereby reinforcing our main findings. Limitations in sample size $>200$ days after infection also increased our time-to-negative and modeling uncertainty. Our estimates of the time-tonegativity are dependent on the negative thresholds and lower limits of detection (LLOD) of the assay. However, our model fits as well as estimates of antibody decay and titers (Figure 1) are not dependent on the assay's LLOD.

No definitive quantitative or qualitative correlate-of-protection has been identified yet for SARS-CoV-2 infection, disease or onward transmission. Nevertheless, live viral neutralization assays remain the gold-standard in vitro correlate-of-protection against viral infection; as such, lack of formal 'authentic' neutralization tests is a study limitation. However, ACE-2-receptor competition assays, such as this MSD assay, have been shown to correlate well with formal viral neutralization assays, enabling use as suitable surrogate functional tests [49]. Recent studies have highlighted the potential for SARS-CoV-2 to gain entry to epithelial cells via CD147 receptor [50]. Blocking of this receptor was not quantified by our competition assay; whether this influences the correlation with in vivo neutralization is unknown.

Finally, to what extent and at what threshold long-term detectable antibodies induce sterilizing immunity, limit transmission, or simply attenuate disease severity, remains to be seen. Human reinfection studies and plaque-reduction assays $>1$-year post-infection are required to clarify this further. SARS-CoV-2-specific T- and B-memory cellular responses must also be characterised to accurately determine durability of immunity. Similarly, mucosal antibody responses may play an important role in the overall protective immune response, 
particularly in early infection. The neutralizing capability and duration of mucosal $\lg A$ responses are currently being studied from the same cohort.

In summary, this prospective cohort study has demonstrated the persistence of SARS-CoV2 S-antibody in $>95 \%$ of individuals up to 200 days post infection. Our lowest bound continuous decay model, predicted that $95 \%$ of individuals would continue to have detectable S-antibody at 465 days while our upper bound gamma-plateau model predicted that S-antibody would plateau at detectable levels indefinitely. The long-term presence of functional $S$ (and RBD) antibody has important implications for the duration of protective immunity following natural infection. It remains to be seen whether novel SARS-CoV-2 vaccine candidates will replicate the long-lasting $S$-antibody duration induced by natural infection.

\section{Materials and methods}

\section{Study setting and design}

Co-STARS was a 1-year single-centre, two-arm, prospective cohort study of healthcare workers at Great Ormond Street Hospital for Children, London (GOSH). The study was approved to start by the UK NHS Health Research Authority on 29th April 2020 and registered on ClinicalTrials.gov (NCT04380896). Informed consent was obtained from all participants. The Study Protocol and Supplementary Methods and Materials submitted with this paper include detailed methods, power calculations and the data analysis approach.

\section{Study participants:}

All hospital staff members $\geq 18$ years of age were eligible for the study, provided they did not display symptoms consistent with SARS-CoV-2 infection at recruitment. Those significantly immunosuppressed or those who had previously received blood products (including immunoglobulins or convalescent sera) since September 2019 were excluded from the study.

\section{Data Collection}


Participants undertook a detailed, standardised online questionnaire at study entry. This included socio-demographic factors, details of previous exposure to and symptomatic episodes consistent with COVID-19, any subsequent complications, previous SARS-CoV-2 diagnostic test results, past medical and contact history, and a comprehensive assessment of risk factors for exposure, susceptibility to infection and severe disease. Blood samples were also taken at baseline and each follow-up visit for determination of SARS-CoV2 serology.

\section{Measurement of SARS-CoV-2 serum antibody and viral RNA by PCR}

All 3657 participants underwent a screening ELISA with the EDI ${ }^{\mathrm{TM}}$ assay. Those that were identified as seropositive by the $\mathrm{EDI}^{\mathrm{TM}}$ assay and provided 2 or more samples had serology repeated by the Meso Scale Discovery (MSD) Chemiluminescent assay that simultaneously detects and quantifies anti-SARS-CoV-2 IgG specific for trimeric S-protein, RBD and $\mathrm{N}$ protein.

\section{Follow-Up Appointments}

All seropositive participants were followed up monthly for repeat antibody testing. Seronegative participants were followed up 6-monthly. At each follow-up visit, participants completed a shortened version of the baseline questionnaire, focussing on any recurrent COVID-19 exposure and/or symptoms.

\section{Study outcomes}

The primary outcome of the study was to establish humoral dynamics following SARS-CoV-2 infection. Kaplan Meier survival analysis was used to compare and plot the time-to-negativity for each antibody. Two mixed effects gamma models were used to predict the antibody trajectory over time (Supplementary Methods). The "gamma-decay model" hypothesized continuous antibody decay and did not account for long-lived plasma cell antibody production. In contrast, the "gamma-plateau" model allowed for two phases of plasma cell production: 'short-lived' plasma cells followed by a subsequent robust long-lived plasma cell (LLPC) response that maintains circulating long-term antibody titers [51].

\section{Surrogate Neutralization Assay}


An MSD® 96-well Custom Competition Assay designed to measure the inhibition of ACE-2 receptor binding to $S$ or RBD by serum-derived antibody (MSD, Maryland) was run on 94 serial samples from 46 participants (two participants had 3 serial samples) in order to establish in vitro correlates of functional immunity. 


\section{Notes}

\section{Author Contributions}

The first draft of the manuscript was prepared by: LG, AS, AT, TL, JH, RT, MH, TB, MJ, HW, ER, AM, CC, JB, KG, DG

The study was designed and implemented by: LG, AS, AT, TL, JH, RT, MH, TB, MJ, HW, ER, AM, CC, JB, KG, DG \& the Co-Stars Team. Testing for SARS-CoV-2 RNA and antibody was conducted by: LG, AS, AT, TL, JH, RT, MH, TB, MJ, HW, ER, AM, CC, JB, KG, DG

Acknowledgements: We would like to dedicate this article to the staff members who died of COVID-19 at Great Ormond Street Hospital during the first wave of the pandemic. We would also like to thank all the staff at Great Ormond Street Hospital who have taken part in the study. In addition, we are very grateful for all the hard work undertaken by the Great Ormond Street laboratory staff and the staff in the immunology laboratories both in the Camelia Botnar Laboratory and the Great Ormond Street Institute of Child Health who ensured that all the PCR tests and serological assays were completed in a timely manner. Finally, we would like to acknowledge the support of the Great Ormond Street Hospital Research \& Development, Governance, Finance, Management, Estates, Operations and Communications departments.

Ethics Statement: This study was approved by the UK Health Research Authority (www.hra.nhs.uk) and registered with www.clinical-trials.gov (NCT04380896). Written informed consent was obtained from all participants before recruitment to the study.

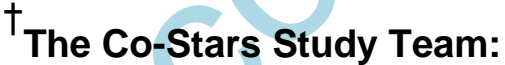

$\begin{array}{llll}\begin{array}{lll}\text { Dorcas Mirambe- } \\ \text { Korsah }\end{array} & \begin{array}{l}\text { Fernanda Fenn } \\ \text { Torrente }\end{array} & \begin{array}{l}\text { Jakub } \\ \text { Wyszynski }\end{array} & \text { Victoria Gander } \\ \text { Amy Leonard } & \text { Louise Myers } & \text { Aimee Vallot } & \text { Camille Paillas } \\ \text { Rose Fitzgerald } & \text { Adam Twigg } & \text { Rabia Manaf } & \text { Lois Gibbons } \\ \text { Hollie Powell } & \text { Richard Nar-Dorh } & \text { Ally Gray } & \text { Elias Fernandez } \\ \text { Aline Minja } & \text { Emily Beech } & \text { Waffa Girshab } & \text { Pei Shi Chia }\end{array}$




\begin{tabular}{|c|c|c|c|}
\hline Kate Webb & Malti Nakrani & Kim Gardiner & Valerija Karaluka \\
\hline Karen Ryan & Dorothy Lee & Katie Groves & Hamad Khan \\
\hline Shamime Nsubuga & $\begin{array}{l}\text { Olivia Rosie- } \\
\text { Wilkinson }\end{array}$ & Julia Spires & $\begin{array}{l}\text { Nuria Sanchez- } \\
\text { Clemente }\end{array}$ \\
\hline Sapriya Kaur & Natasha Carroll & Jemma Efford & Gabriel Bredin \\
\hline $\begin{array}{l}\text { Celma Marisa Dos } \\
\text { Santos Domingues }\end{array}$ & Sophie Foxall & Helen Ashton & Abbey Afzal \\
\hline Sally Mainland & Kate Crumpler & $\begin{array}{l}\text { Lucinda } \\
\text { Dawson }\end{array}$ & Claire \\
\hline Maria Tabbu & Laura Chiverton & Jade Sugars & Jordan Mooney \\
\hline Dorothy Chikusu & Fariba Tahami & Baratth Samy & Shomona Begum \\
\hline Dhimple Patel & Philippa Wiltshire & nnis Suc & Anna Ryan \\
\hline Luke Lancaster & Kavita Thind & Kate & Rachel Sterling \\
\hline Connor Tugulu & Sandhya Ghurburrun & Steffi Gray & Joy Mugas \\
\hline Moe Kishma & Kathleen Akpokomua & Sophie White & Eleana Pieri \\
\hline Sabina Shamsad & Demi Alexandrou & Odera Aguele & Katherine Miles \\
\hline Anamika Jain & Subishma Gautam & Oliver Simms & Rachel Goff \\
\hline Zarif Shams & Tinya Chirinda & Aaliya Nur & Tarekur Rahman \\
\hline
\end{tabular}

Financial Support: LG was supported by the Wellcome Trust (201470/Z/16/Z), the National Institute of Allergy and Infectious Diseases of the National Institutes of Health under award number 1R01Al146338, the GOSH Charity (VC0921) and the GOSH/ICH Biomedical Research Centre (www.nihr.ac.uk). AS was supported by the Wellcome Trust $(220565 / Z / 20 / Z)$. The funders had no role in the study design, data collection and analysis, decision to publish, or preparation of the manuscript.

Potential Conflicts of Interest: All No reported conflicts of interest. All authors have submitted the ICMJE Form for Disclosure of Potential Conflicts of Interest. Conflicts that the editors consider relevant to the content of the manuscript have been disclosed. The authors have declared that no competing interests exist. 


\section{References}

1. Guan W, Ni Z, Hu Y, et al. Clinical Characteristics of Coronavirus Disease 2019 in China. New England Journal of Medicine 2020; 382:1708-1720. Available at: https://doi.org/10.1056/NEJMoa2002032. Accessed 30 October 2020.

2. Dong E, Du H, Gardner L. An interactive web-based dashboard to track COVID-19 in real time. The Lancet Infectious Diseases 2020; 20:533-534. Available at: https://www.thelancet.com/journals/laninf/article/PIIS1473-3099(20)30120-1/abstract. Accessed 30 October 2020.

3. Immune responses and immunity to SARS-CoV-2. Available at: https://www.ecdc.europa.eu/en/covid-19/latest-evidence/immune-responses. Accessed 30 October 2020.

4. Walls AC, Park Y-J, Tortorici MA, Wall A, McGuire AT, Veesler D. Structure, Function, and Antigenicity of the SARS-CoV-2 Spike Glycoprotein. Cell 2020; 181:281292.e6. Available at: https://www.ncbi.nlm.nih.gov/pmc/articles/PMC7102599/. Accessed 30 October 2020.

5. Characterization of spike glycoprotein of SARS-CoV-2 on virus entry and its immune cross-reactivity with SARS-CoV | Nature Communications. Available at: https://www.nature.com/articles/s41467-020-15562-9. Accessed 30 October 2020.

6. Cong Y, Ulasli M, Schepers H, et al. Nucleocapsid Protein Recruitment to Replication-Transcription Complexes Plays a Crucial Role in Coronaviral Life Cycle. Journal of Virology 2020; 94. Available at: https://jvi.asm.org/content/94/4/e01925-19. Accessed 30 October 2020.

7. Ju B, Zhang Q, Ge J, et al. Human neutralizing antibodies elicited by SARS-CoV-2 infection. Nature 2020; 584:115-119. Available at: https://www.nature.com/articles/s41586020-2380-z. Accessed 30 October 2020.

8. Imai M, Iwatsuki-Horimoto K, Hatta M, et al. Syrian hamsters as a small animal model for SARS-CoV-2 infection and countermeasure development. PNAS 2020; 117:16587-16595. Available at: https://www.pnas.org/content/117/28/16587. Accessed 30 October 2020.

9. Rogers TF, Zhao F, Huang D, et al. Isolation of potent SARS-CoV-2 neutralizing antibodies and protection from disease in a small animal model. Science 2020; 369:956963. Available at: https://science.sciencemag.org/content/369/6506/956. Accessed 30 October 2020.

10. Suthar MS, Zimmerman MG, Kauffman RC, et al. Rapid Generation of Neutralizing Antibody Responses in COVID-19 Patients. Cell Reports Medicine 2020; 1:100040. 
Available at: https://linkinghub.elsevier.com/retrieve/pii/S2666379120300525. Accessed 30 October 2020.

11. Ni L, Ye F, Cheng M-L, et al. Detection of SARS-CoV-2-Specific Humoral and Cellular Immunity in COVID-19 Convalescent Individuals. Immunity 2020; 52:971-977.e3. Available at: http://www.sciencedirect.com/science/article/pii/S1074761320301813. Accessed 30 October 2020.

12. Cao W-C, Liu W, Zhang P-H, Zhang F, Richardus JH. Disappearance of antibodies to SARS-associated coronavirus after recovery. N Engl J Med 2007; 357:1162-1163.

13. Mo H, Zeng G, Ren X, et al. Longitudinal profile of antibodies against SARScoronavirus in SARS patients and their clinical significance. Respirology 2006; 11:49-53.

14. Chia WN, Tan CW, Foo R, et al. Serological differentiation between COVID-19 and SARS infections. Emerging Microbes \& Infections 2020; 9:1497-1505. Available at: https://doi.org/10.1080/22221751.2020.1780951. Accessed 30 October 2020.

15. Guo X, Guo Z, Duan C, et al. Long-Term Persistence of IgG Antibodies in SARSCoV Infected Healthcare Workers. medRxiv 2020; :2020.02.12.20021386. Available at: https://www.medrxiv.org/content/10.1101/2020.02.12.20021386v1. Accessed 3 November 2020.

16. Isho B, Abe KT, Zuo M, et al. Persistence of serum and saliva antibody responses to SARS-CoV-2 spike antigens in COVID-19 patients. Science Immunology 2020; 5 . Available at: https://immunology.sciencemag.org/content/5/52/eabe5511. Accessed 12 October 2020.

17. lyer AS, Jones FK, Nodoushani A, et al. Persistence and decay of human antibody responses to the receptor binding domain of SARS-CoV-2 spike protein in COVID-19 patients. Science Immunology 2020; 5 . Available at:

https://immunology.sciencemag.org/content/5/52/eabe0367. Accessed 12 October 2020.

18. Ripperger TJ, Uhrlaub JL, Watanabe M, et al. Orthogonal SARS-CoV-2 Serological Assays Enable Surveillance of Low-Prevalence Communities and Reveal Durable Humoral Immunity. Immunity 2020; :S1074761320304453. Available at:

https://linkinghub.elsevier.com/retrieve/pii/S1074761320304453. Accessed 5 November 2020.

19. Long Q-X, Tang X-J, Shi Q-L, et al. Clinical and immunological assessment of asymptomatic SARS-CoV-2 infections. Nature Medicine 2020; 26:1200-1204. Available at: https://www.nature.com/articles/s41591-020-0965-6. Accessed 30 October 2020.

20. Ibarrondo FJ, Fulcher JA, Goodman-Meza D, et al. Rapid Decay of Anti-SARS-CoV2 Antibodies in Persons with Mild Covid-19. New England Journal of Medicine 2020; 383:1085-1087. Available at: https://doi.org/10.1056/NEJMc2025179. Accessed 12 October 2020.

21. Loss of Anti-SARS-CoV-2 Antibodies in Mild Covid-19. New England Journal of Medicine 2020; 383:1694-1698. Available at: https://doi.org/10.1056/NEJMc2027051. Accessed 3 November 2020. 
22. Seow J, Graham C, Merrick B, et al. Longitudinal evaluation and decline of antibody responses in SARS-CoV-2 infection. medRxiv 2020; :2020.07.09.20148429. Available at: https://www.medrxiv.org/content/10.1101/2020.07.09.20148429v1. Accessed 12 October 2020.

23. Wajnberg A, Amanat F, Firpo A, et al. SARS-CoV-2 infection induces robust, neutralizing antibody responses that are stable for at least three months. medRxiv 2020; :2020.07.14.20151126. Available at:

https://www.medrxiv.org/content/10.1101/2020.07.14.20151126v1. Accessed 13 October 2020.

24. Crawford KHD, Dingens AS, Eguia R, et al. Dynamics of neutralizing antibody titers in the months after SARS-CoV-2 infection. J Infect Dis Available at:

https://academic.oup.com/jid/advance-article/doi/10.1093/infdis/jiaa618/5916372. Accessed 6 November 2020.

25. Tan Y, Liu F, Xu X, et al. Durability of neutralizing antibodies and T-cell response post SARS-CoV-2 infection. Front Med 2020; Available at: https://doi.org/10.1007/s11684020-0822-5. Accessed 3 November 2020.

26. Piccoli L, Park Y-J, Tortorici MA, et al. Mapping Neutralizing and Immunodominant Sites on the SARS-CoV-2 Spike Receptor-Binding Domain by Structure-Guided HighResolution Serology. Cell 2020; 183:1024-1042.e21.

27. Wu J, Liang B, Chen C, et al. SARS-CoV-2 infection induces sustained humoral immune responses in convalescent patients following symptomatic COVID-19. medRxiv 2020; :2020.07.21.20159178. Available at:

https://www.medrxiv.org/content/10.1101/2020.07.21.20159178v1. Accessed 13 October 2020.

28. Zhao X, Ning Y, Chen MI-C, Cook AR. Individual and Population Trajectories of Influenza Antibody Titers Over Multiple Seasons in a Tropical Country. Am J Epidemiol 2018; 187:135-143. Available at: https://academic.oup.com/aje/article/187/1/135/3896092. Accessed 2 November 2020.

29. Fraser C, Tomassini JE, Xi L, et al. Modeling the long-term antibody response of a human papillomavirus (HPV) virus-like particle (VLP) type 16 prophylactic vaccine. Vaccine 2007; 25:4324-4333. Available at:

http://www.sciencedirect.com/science/article/pii/S0264410X07002320. Accessed 2 November 2020.

30. Andraud M, Lejeune O, Musoro JZ, Ogunjimi B, Beutels P, Hens N. Living on Three Time Scales: The Dynamics of Plasma Cell and Antibody Populations Illustrated for Hepatitis A Virus. PLOS Computational Biology 2012; 8:e1002418. Available at: https://journals.plos.org/ploscompbiol/article?id=10.1371/journal.pcbi.1002418. Accessed 2 November 2020.

31. Pollán M, Pérez-Gómez B, Pastor-Barriuso R, et al. Prevalence of SARS-CoV-2 in Spain (ENE-COVID): a nationwide, population-based seroepidemiological study. The Lancet 
2020; :S0140673620314835. Available at:

https://linkinghub.elsevier.com/retrieve/pii/S0140673620314835. Accessed 8 July 2020.

32. Slifka MK, Amanna IJ. Role of Multivalency and Antigenic Threshold in Generating Protective Antibody Responses. Front Immunol 2019; 10. Available at:

https://www.frontiersin.org/articles/10.3389/fimmu.2019.00956/full. Accessed 10 November 2020.

33. Dörner T, Radbruch A. Antibodies and B Cell Memory in Viral Immunity. Immunity 2007; 27:384-392. Available at: https://www.cell.com/immunity/abstract/S10747613(07)00420-7. Accessed 10 November 2020.

34. Amanna IJ, Slifka MK. Mechanisms that determine plasma cell lifespan and the duration of humoral immunity. Immunol Rev 2010; 236:125-138. Available at: https://www.ncbi.nlm.nih.gov/pmc/articles/PMC7165522/. Accessed 10 November 2020.

35. Khodadadi L, Cheng Q, Radbruch A, Hiepe F. The Maintenance of Memory Plasma Cells. Front Immunol 2019; 10. Available at:

https://www.ncbi.nlm.nih.gov/pmc/articles/PMC6464033/. Accessed 10 November 2020.

36. Nguyen DC, Joyner CJ, Sanz I, Lee FE-H. Factors Affecting Early Antibody Secreting Cell Maturation Into Long-Lived Plasma Cells. Front Immunol 2019; 10. Available at: https://www.frontiersin.org/articles/10.3389/fimmu.2019.02138/full. Accessed 10 November 2020.

37. Bonsignori M, Moody MA, Parks RJ, et al. HIV-1 Envelope Induces Memory B Cell Responses That Correlate with Plasma Antibody Levels after Envelope gp120 Protein Vaccination or HIV-1 Infection. The Journal of Immunology 2009; 183:2708-2717. Available at: https://www.jimmunol.org/content/183/4/2708. Accessed 10 November 2020.

38. Srinivasan S, Cui H, Gao Z, et al. Structural Genomics of SARS-CoV-2 Indicates Evolutionary Conserved Functional Regions of Viral Proteins. Viruses 2020; 12:360.

Available at: https://www.mdpi.com/1999-4915/12/4/360. Accessed 10 November 2020.

39. Wajnberg A, Amanat F, Firpo A, et al. Robust neutralizing antibodies to SARS-CoV-2 infection persist for months. Science 2020; Available at:

https://science.sciencemag.org/content/early/2020/10/27/science.abd7728. Accessed 30 October 2020.

40. Estimates of the severity of coronavirus disease 2019: a model-based analysis - The Lancet Infectious Diseases. Available at:

https://www.thelancet.com/journals/laninf/article/PIIS1473-3099(20)30243-7/fulltext.

Accessed 31 October 2020.

41. Wang C, Li W, Drabek D, et al. A human monoclonal antibody blocking SARS-CoV-2 infection. Nature Communications 2020; $11: 2251$. Available at:

https://www.nature.com/articles/s41467-020-16256-y. Accessed 31 October 2020. 
42. Grifoni A, Weiskopf D, Ramirez SI, et al. Targets of T Cell Responses to SARS-CoV2 Coronavirus in Humans with COVID-19 Disease and Unexposed Individuals. Cell 2020; 181:1489-1501.e15.

43. Le Bert N, Tan AT, Kunasegaran K, et al. SARS-CoV-2-specific T cell immunity in cases of COVID-19 and SARS, and uninfected controls. Nature 2020; 584:457-462.

Available at: https://www.nature.com/articles/s41586-020-2550-z. Accessed 5 November 2020.

44. Juno JA, Tan H-X, Lee WS, et al. Humoral and circulating follicular helper T cell responses in recovered patients with COVID-19. Nature Medicine 2020; 26:1428-1434. Available at: https://www.nature.com/articles/s41591-020-0995-0. Accessed 5 November 2020.

45. Peng $\mathrm{Y}$, Mentzer AJ, Liu G, et al. Broad and strong memory CD4 + and CD8 + T cells induced by SARS-CoV-2 in UK convalescent individuals following COVID-19. Nature Immunology 2020; 21:1336-1345. Available at: https://www.nature.com/articles/s41590-0200782-6. Accessed 5 November 2020.

46. Hicks J, Klumpp-Thomas C, Kalish H, et al. Serologic Cross-Reactivity of SARSCoV-2 with Endemic and Seasonal Betacoronaviruses. Journal of Clinical Immunology 2021; Available at: https://www.meta.org/papers/serologic-cross-reactivity-of-sars-cov-2with/33725211. Accessed 5 May 2021.

47. Kissler SM, Tedijanto C, Goldstein E, Grad YH, Lipsitch M. Projecting the transmission dynamics of SARS-CoV-2 through the postpandemic period. Science 2020; 368:860-868. Available at: https://science.sciencemag.org/content/368/6493/860. Accessed 31 October 2020.

48. Johnson M, Wagstaffe HR, Gilmour KC, et al. Evaluation of a novel multiplexed assay for determining IgG levels and functional activity to SARS-CoV-2. J Clin Virol 2020; 130:104572. Available at: https://www.ncbi.nlm.nih.gov/pmc/articles/PMC7396134/. Accessed 14 October 2020.

49. Walker SN, Chokkalingam N, Reuschel EL, et al. SARS-CoV-2 Assays To Detect Functional Antibody Responses That Block ACE2 Recognition in Vaccinated Animals and Infected Patients. J Clin Microbiol 2020; 58. Available at:

https://www.ncbi.nlm.nih.gov/pmc/articles/PMC7587116/. Accessed 11 May 2021.

50. Seyedpour S, Khodaei B, Loghman AH, et al. Targeted therapy strategies against SARS-CoV-2 cell entry mechanisms: A systematic review of in vitro and in vivo studies. Journal of Cellular Physiology 2021; 236:2364-2392. Available at: https://onlinelibrary.wiley.com/doi/abs/10.1002/jcp.30032. Accessed 29 April 2021.

51. Cyster JG, Allen CDC. B Cell Responses: Cell Interaction Dynamics and Decisions. Cell 2019; 177:524-540. 


\section{Tables}

Table 1 - Demographic details of study participants and variables associated with high peak antibody titers.

\begin{tabular}{|c|c|c|}
\hline & $\begin{array}{c}\text { Number (percentage } \\
\text { and/or IQR) }\end{array}$ & $\begin{array}{l}\text { Association with Increased } \\
\text { Spike Antibody titers. } \\
\text { Coefficient (p-value) }\end{array}$ \\
\hline $\begin{array}{l}\text { Denominator (All study } \\
\text { recruits) }\end{array}$ & 3679 & 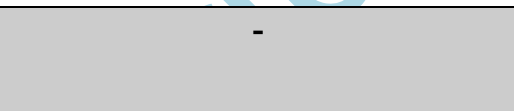 \\
\hline $\begin{array}{l}\text { Primary Outcome } \\
\text { Participants }\end{array}$ & $349(100 \%)$ & - \\
\hline Total Monthly Samples & 1163 & - \\
\hline \multicolumn{3}{|l|}{ Age } \\
\hline $18-30$ & $82(24 \%)$ & Reference \\
\hline $30-40$ & 109 (31\%) & $-0.27(p=0.2)$ \\
\hline $40-50$ & $83(24 \%)$ & $-0.15(p=0.5)$ \\
\hline $50-60$ & $56(16 \%)$ & $0.09(p=0.74)$ \\
\hline $60-70$ & $19(5 \%)$ & $0.24(p=0.5)$ \\
\hline \multicolumn{3}{|l|}{ Sex } \\
\hline Female & $259(80 \%)$ & $-0.3(p=0.2)$ \\
\hline Male & $190(20 \%)$ & \\
\hline \multicolumn{3}{|l|}{ Profession } \\
\hline Allied Health & $83(24 \%)$ & Reference \\
\hline Nurse & $101(29 \%)$ & $0.12(p=0.53)$ \\
\hline Manager & $1(<1 \%)$ & $0.64(p=0.5)$ \\
\hline Cleaner, Caterer or Porter & $18(5 \%)$ & $0.4(p=0.3)$ \\
\hline Doctor & $49(14 \%)$ & $-0.18(p=0.5)$ \\
\hline
\end{tabular}




\begin{tabular}{|c|c|c|}
\hline Scientist & $5(1 \%)$ & $0.23(p=0.7)$ \\
\hline $\begin{array}{l}\text { Symptoms } \\
\text { Anosmia/Ageusia } \\
\text { Cough/Shortness of } \\
\text { Breath/Wheeze } \\
\text { Diarrhoea/Vomiting/ } \downarrow \text { Appetite } \\
\text { Extreme fatigue/Myalgia } \\
\text { Fever/Rigors } \\
\text { Other }\end{array}$ & $\begin{array}{c}201(58 \%) / 210(60 \%) \\
225(64 \%) / 130(37 \%) / \\
67(19 \%) \\
77(22 \%) / 24(7 \%) / 32 \\
(9 \%) \\
199(57 \%) / 225(\%) \\
175(50 \%) / 27(8 \%) \\
174(50 \%)\end{array}$ & $\begin{array}{c}0.54(p=0.01)^{*} \\
0.3(p=0.14) \\
0.3(p=0.13) \\
-0.08(p=0.65) \\
0.37(p=0.03)^{*} \\
\text { Reference }\end{array}$ \\
\hline $\begin{array}{l}\text { Symptom severity } \\
\text { Attended hospital } \\
\text { Admitted to hospital }\end{array}$ & $\begin{array}{l}11(3 \%) \\
1(0.2 \%)\end{array}$ & - \\
\hline $\begin{array}{l}\text { Any Comorbidities } \\
\text { Yes } \\
\text { No }\end{array}$ & $\begin{array}{l}42(13 \%) \\
307(87 \%)\end{array}$ & $\begin{array}{l}0.05(p=0.8) \\
\text { Reference }\end{array}$ \\
\hline $\begin{array}{l}\text { Symptom Duration } \\
\text { (mean, IQR) }\end{array}$ & 24 (IQR 7-27) days & $0.0007(0.8)$ \\
\hline $\begin{array}{l}\text { Ethnic Background } \\
\text { BAME } \\
\text { Non BAME }\end{array}$ & $\begin{array}{l}97(29 \%) \\
252(71 \%)\end{array}$ & $\begin{array}{c}0.42(p=0.018)^{*} \\
\text { Reference }\end{array}$ \\
\hline $\begin{array}{l}\text { BMI } \\
18-25\end{array}$ & 91 & Reference \\
\hline $\begin{array}{l}25-30 \\
30-40\end{array}$ & $\begin{array}{l}42 \\
34\end{array}$ & $\begin{array}{l}0.57(p=0.03)^{*} \\
0.69(p=0.03)^{*}\end{array}$ \\
\hline Missing/Unknown BMI & 182 & NA \\
\hline
\end{tabular}




\section{Figure Legends}

Figure 1 - Serial monthly serological measurements from 349 participants up to 262 days following symptoms of SARS-CoV-2. Samples from the same participant are linked with a thin black line and the red-dotted line is shown to indicate seroreversion. The gammaplateau model is superimposed to show antibody trajectory: The predicted antibody trajectory (black line) is the median of the posterior distribution of the best model fit and 95\% $\mathrm{Cl}$ with and without individual effects (light blue and dark blue shading respectively) a) The spike (S) protein b) RBD antibody and c) the nucleoprotein $(\mathrm{N})$ antibody with a relatively steep rate of decay.

Figure 2 - Parallel serological measurements of the Spike, RBD and Nucleoprotein antibodies from the start of symptoms. Repeated serological measurements to the spike (S, Blue), RBD (Green) and the nucleoprotein (N, Red) demonstrating the time to a negative test from all possible starting positive tests. The initial number of seropositive participants providing the first sample and the subset still enrolled in the study at any given time point are provided in the table below the graphic. The 95\% confidence intervals of this uncertainty are represented by shaded areas around the lines.

Figure 3 - Modeled predicted time to seronegativity from symptom onset. Model based predictions of time to seronegativity. a, Comparison of the three tested antibodies against the S-protein (S, blue), receptor-binding domain (RBD, green) and nucleoprotein ( $N$, red) for the gamma plateau model (top) and the gamma decay model (bottom). b, Differences between the two proposed models, the gamma plateau model (blue) and the gamma decay model (red) for the three tested antibodies ( $\mathrm{S}$; top right, RBD; bottom, and N; top left). Coloured lines represent the median estimates of the posterior density, while the shaded ribbons encompass the $95 \%$ confidence interval.

Figure 4 a, b, c, d, e) - Measured and Modeled Weekly Mean Antibody Titer. Real data (green), gamma-plateau model (red), gamma-decay model (blue) for a) the spike antibody, b) the RBD antibody and c) the nucleoprotein antibody. Modeled half-lives of antibody decay for d) The gamma-plateau model and e) gamma-decay model. Colors represent the three different antibodies tested: those for the spike protein (blue), nucleoprotein protein (red), and receptor-binding domain (green).

Figure 5 - Surrogate neutralization assay (spike and RBD) and how this maps to the final predicted titers at plateau. a,b Percentage binding plotted against antibody titer. Red line represents the median amount of antibody titer at which the change in percentage binding is greatest, with the $95 \% \mathrm{Cl}$ indicated by dotted red lines. Black line is the median 
posterior distribution of the generalized logistic model, while the blue ribbon represents the $95 \% \mathrm{Cl}$. c,d, Posterior distribution of the antibody titers at the long-term plateau as predicted by the gamma-plateau model. Shaded grey area corresponds to the threshold of seronegativity. 


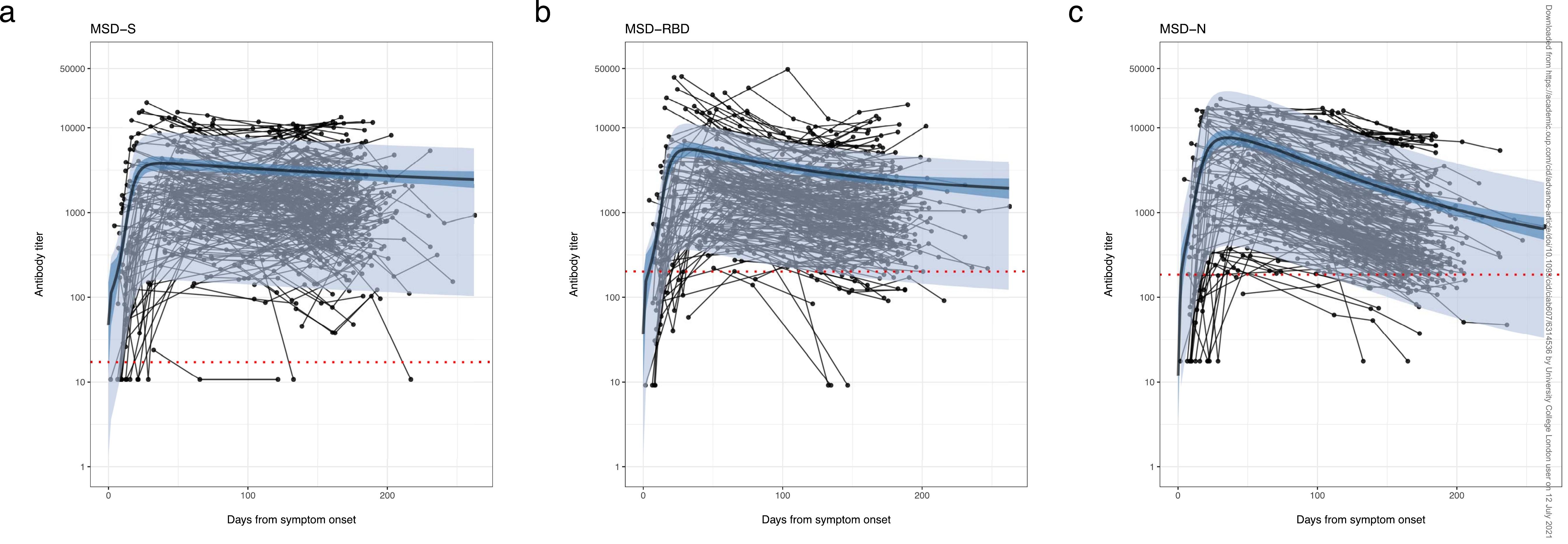

b

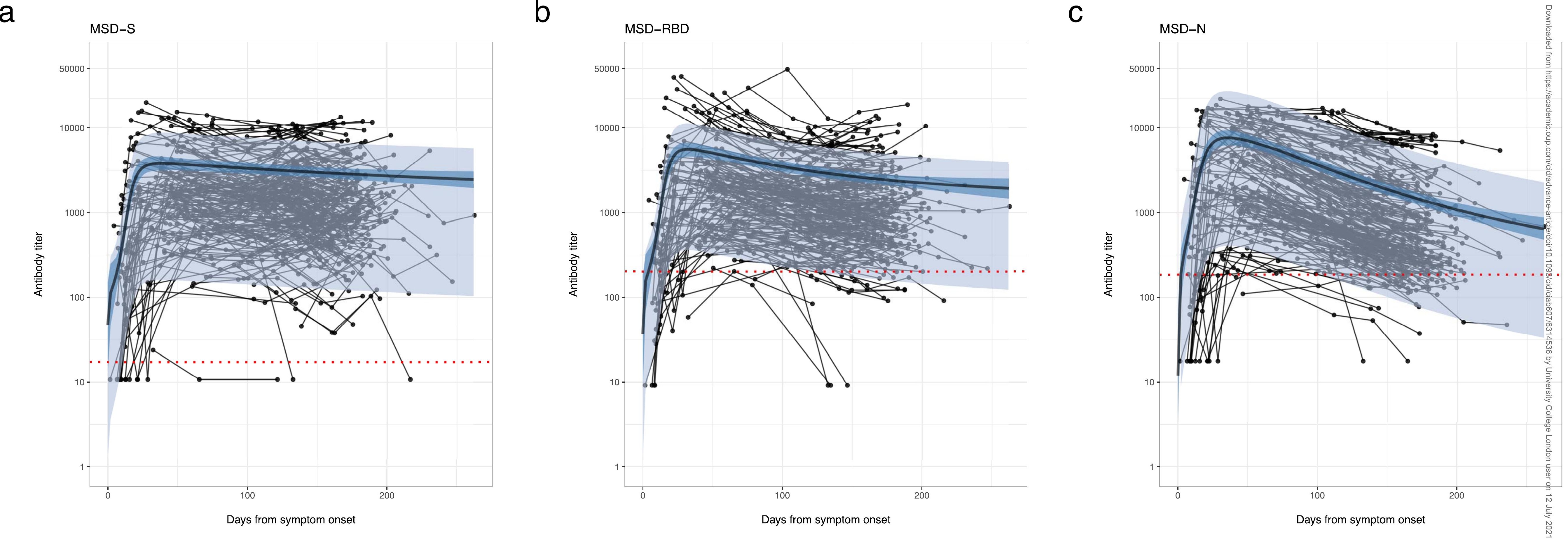

Days from symptom onset

C MSD-N

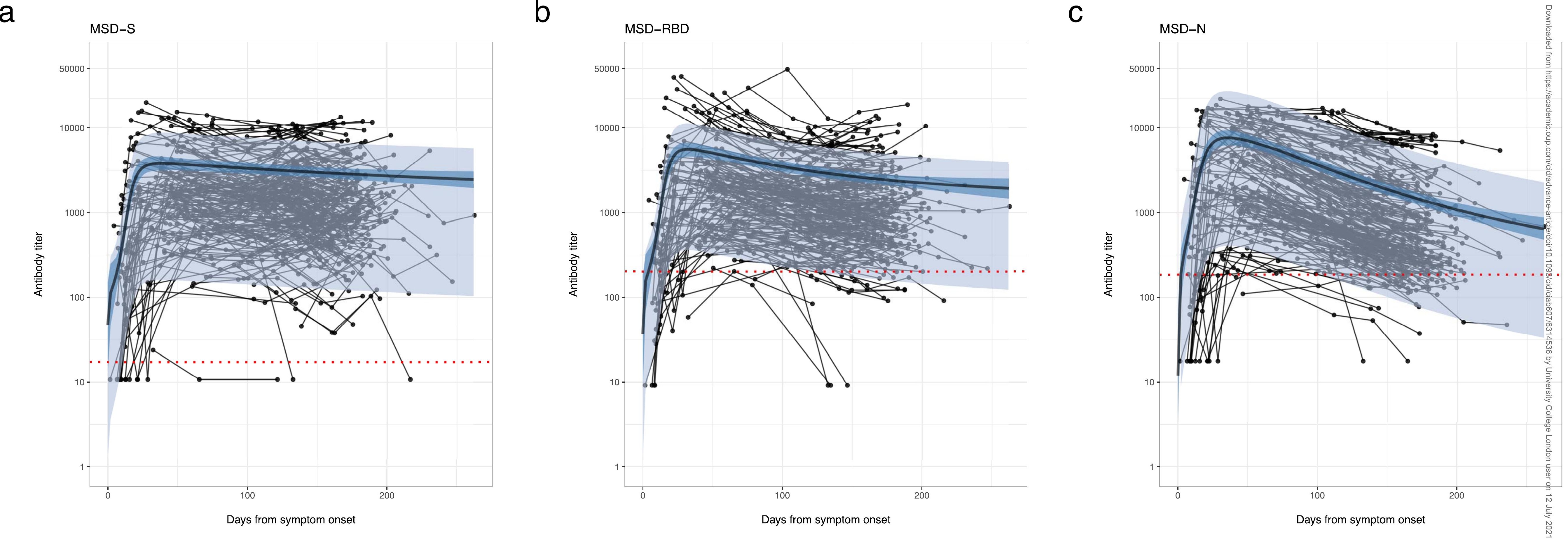

Days from symptom onset 


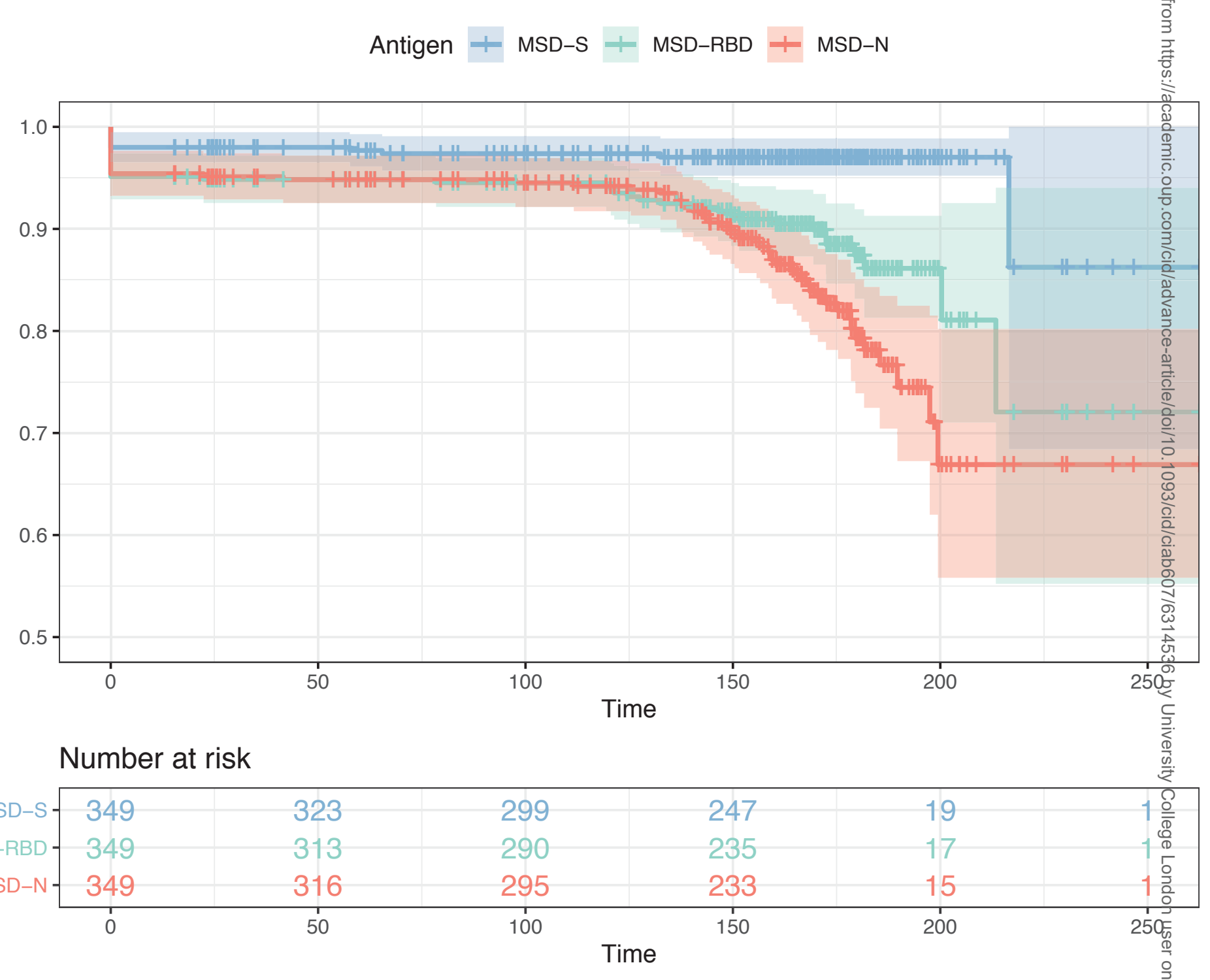


a

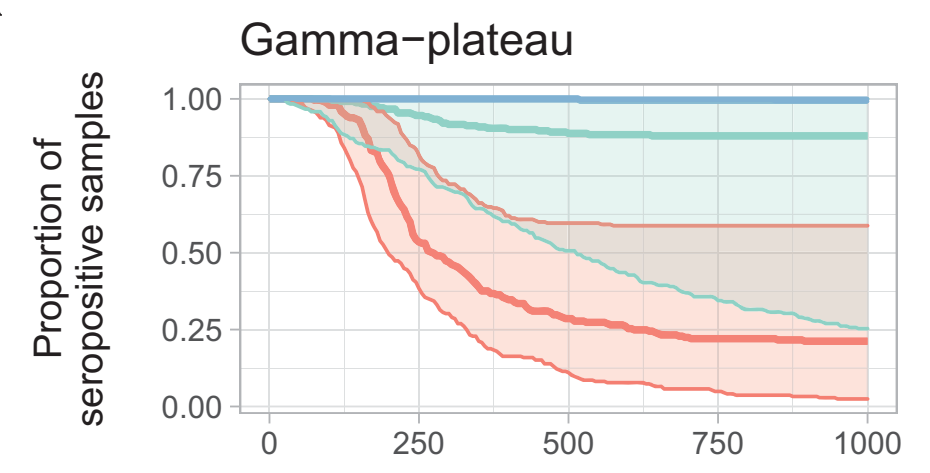

Days from symptom onset

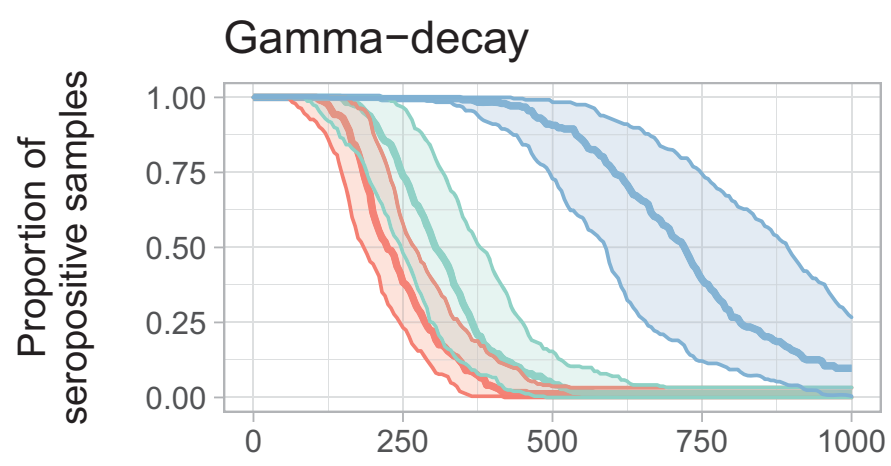

Days from symptom onset b

Antigen

\begin{tabular}{|c|}
\hline \\
\hline \\
\hline $\begin{array}{l}\text { MSD-N } \\
\text { MSD-RBD } \\
\text { MSD-S }\end{array}$ \\
\hline
\end{tabular}
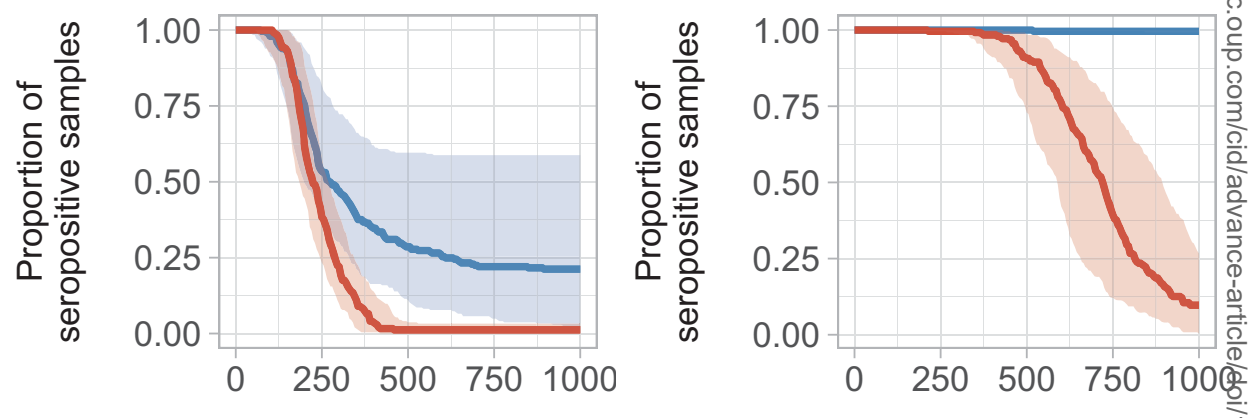

Days from symptom onset MSD-RBD

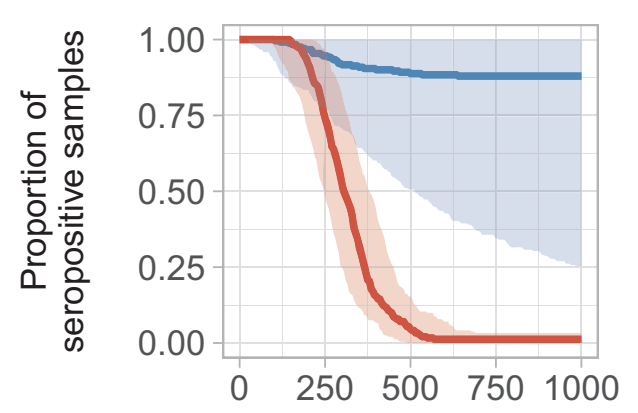

Model

- Gamma-plateau

Gamma-decay 
a

MSD-S

b

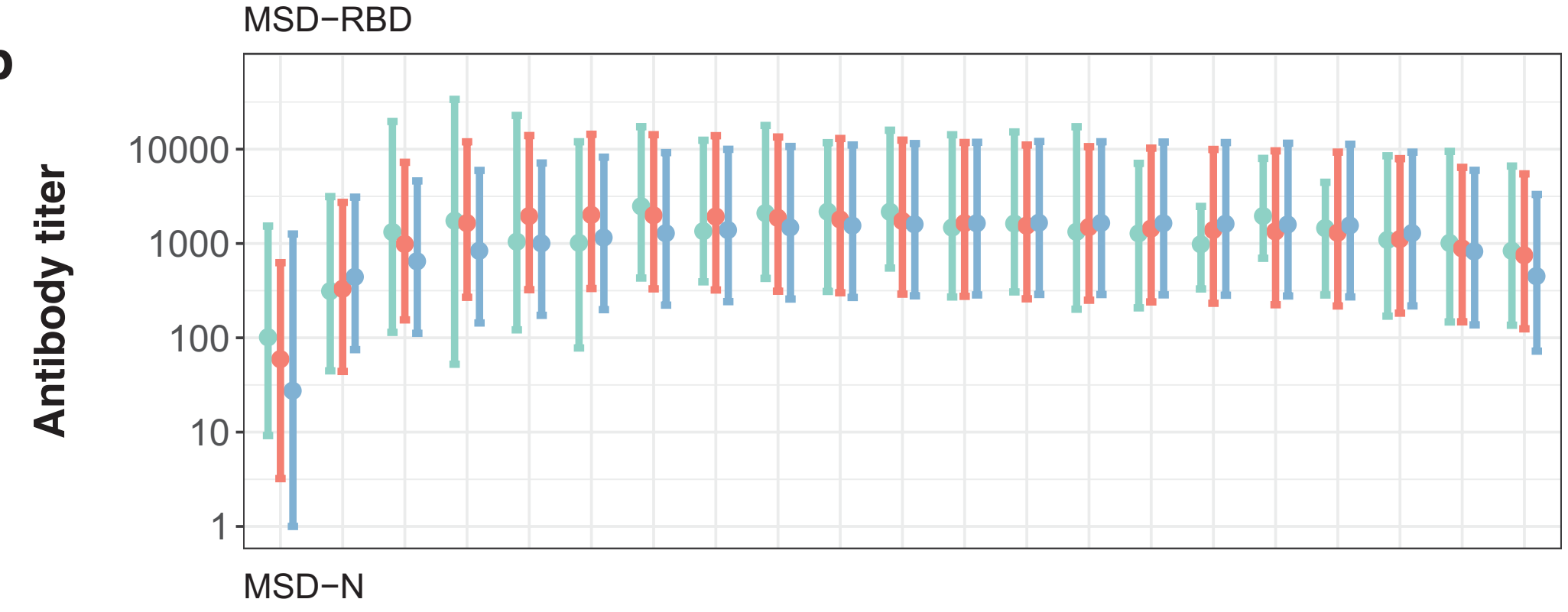

C

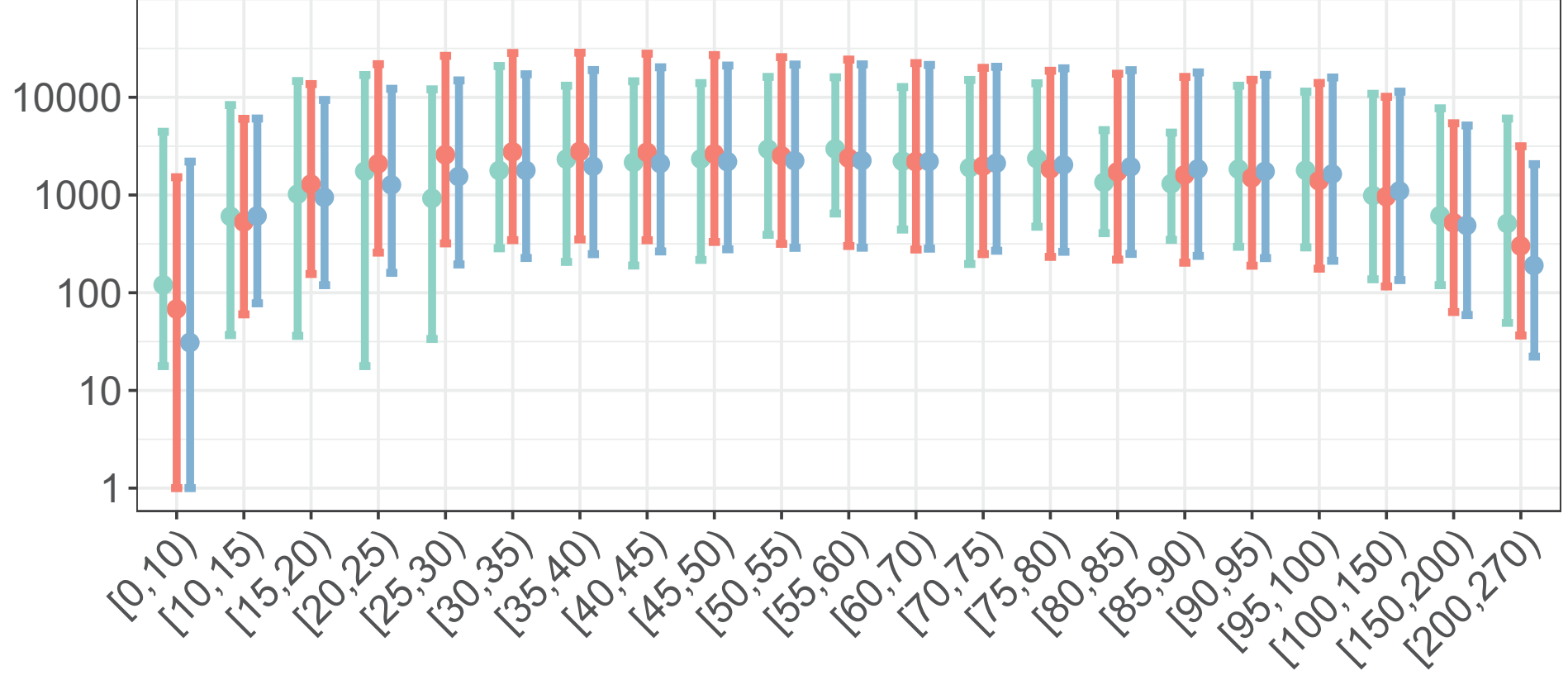

Days after symptom onset

Model $\approx$ Real data $\approx$ Gamma plateau $\approx$ Gamma decay

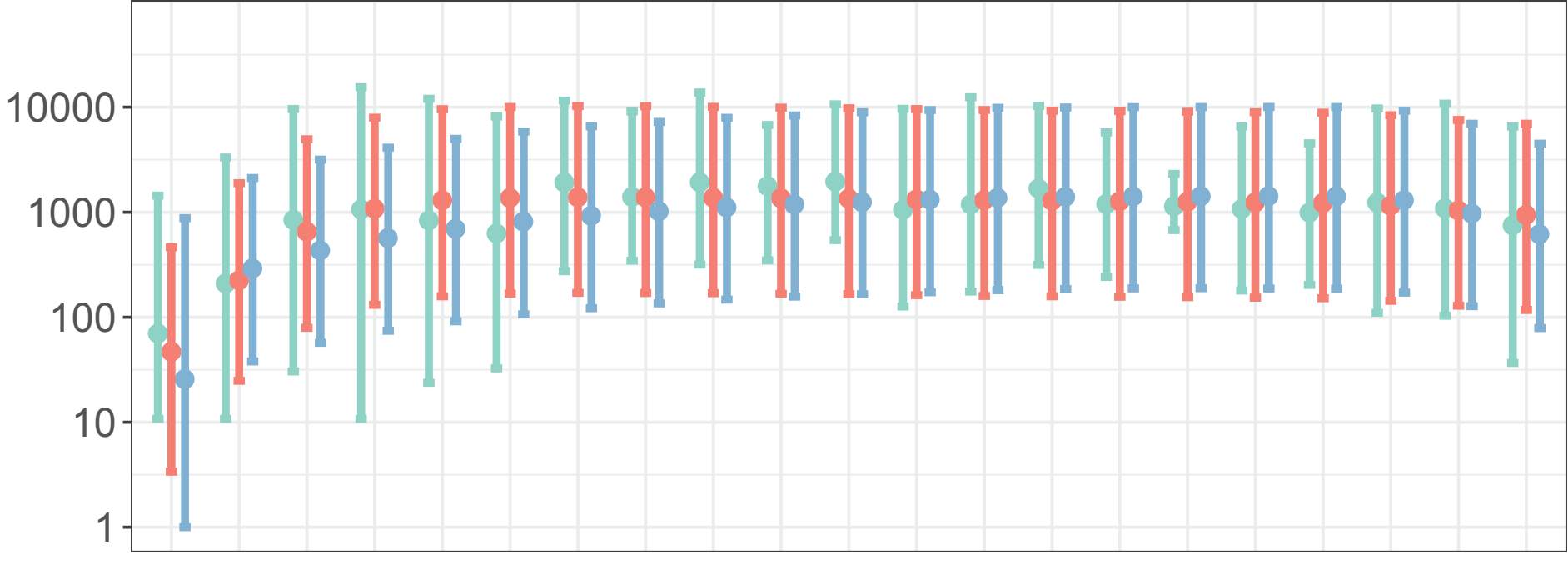

d

Gamma-plateau

e Gamma-decay
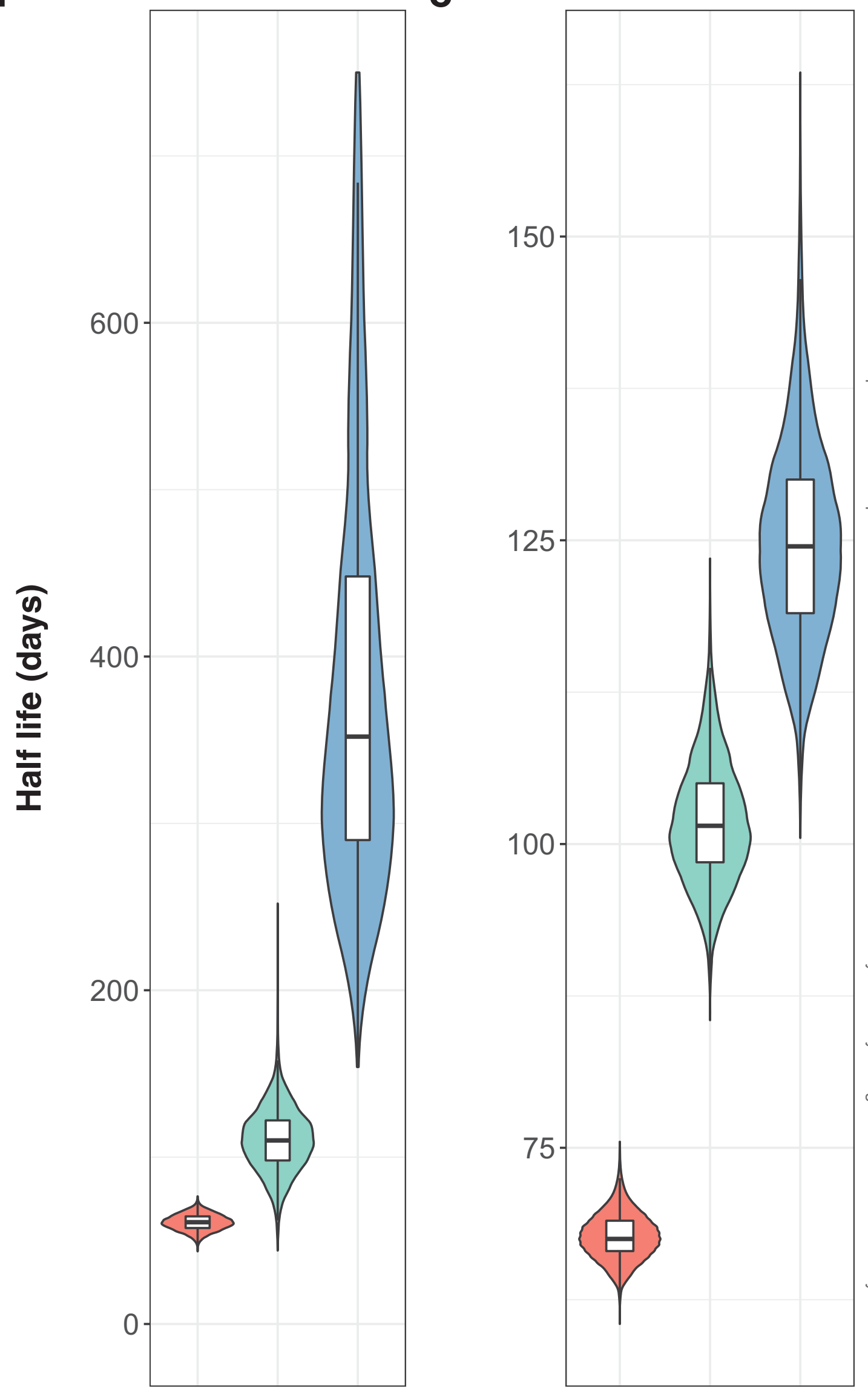

Antigen

MSD-N $\square$ MSD-RBD 
a

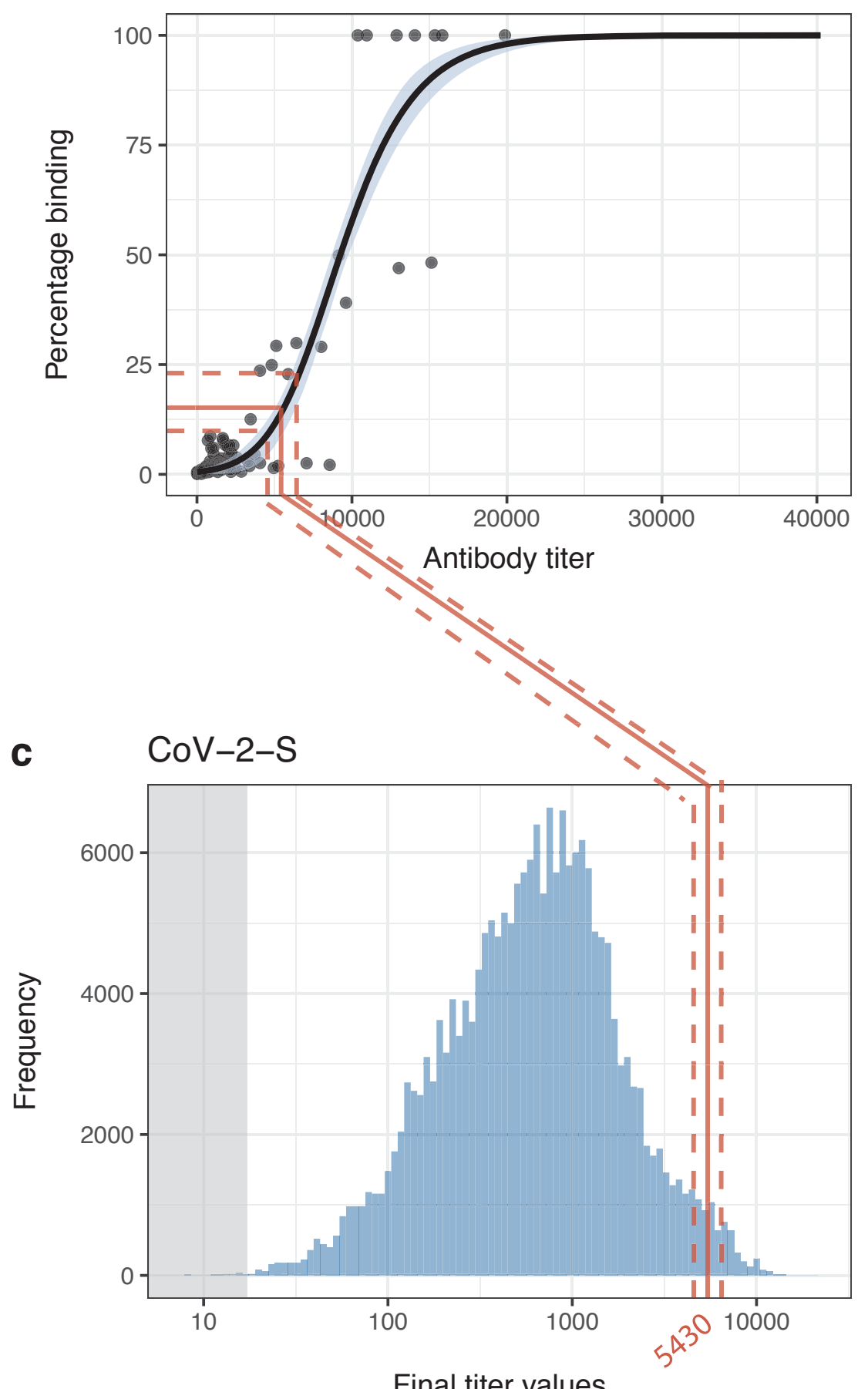

b

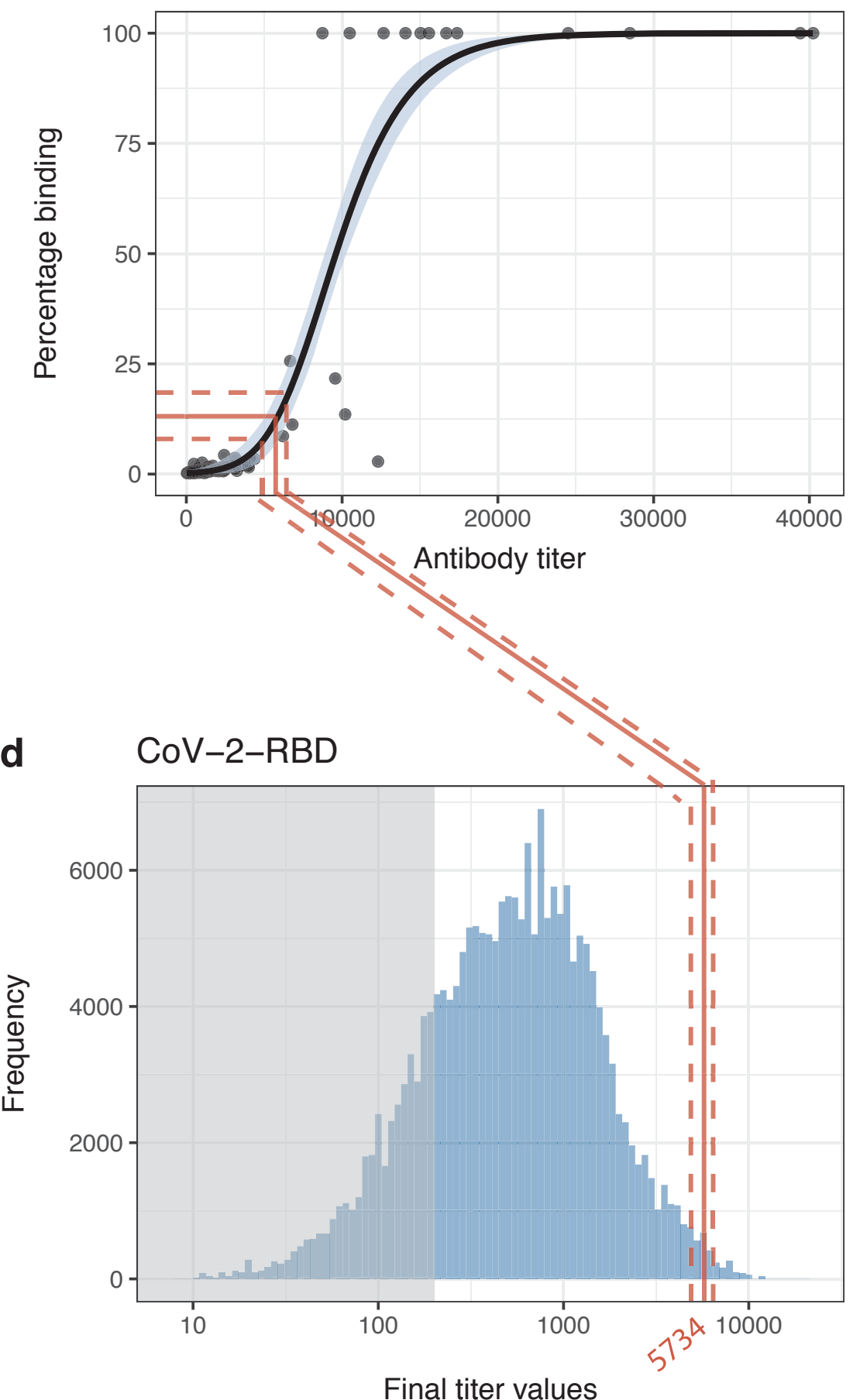

